\title{
Vetiver growth with different fertilizations in quartzite mining tailings
}

\author{
Cristiany Silva Amaral ${ }^{1}$ (D), Enilson de Barros Silva ${ }^{1}$ (D), Israel Marinho Pereira ${ }^{1}$ (D), \\ Wander Amaral ${ }^{1}$ (D), Michele Aparecida Pereira da Silva ${ }^{2}$ (D), \\ Bárbara Olinda Nardis ${ }^{2}$
}

${ }^{1}$ Universidade Federal dos Vales do Jequitinhonha e Mucuri - UFVJM, Diamantina/MG, Brasil
${ }^{2}$ Universidade Federal de Lavras - UFLA, Lavras/MG, Brasil

\begin{abstract}
The objective of this work was to evaluate the behavior of Vetiveria zizanioides when grown in tailings from quartzite mining. A greenhouse experiment was conducted in a completely randomized experimental design with four replicates. The treatments consisted of five combinations of organic (OF) and mineral fertilization (MF) and an additional treatment of the tailings without OF or MF (control). The combinations were $0 \% \mathrm{OF} / 100 \% \mathrm{MF}, 25 \% \mathrm{OF} / 75 \% \mathrm{MF}, 50 \% \mathrm{OF} / 50 \% \mathrm{MF}$, $75 \% \mathrm{OF} / 25 \% \mathrm{MF}$, and $100 \% \mathrm{OF} / 0 \% \mathrm{MF}$. The doses of $100 \%$ of MF and OF were $0.025 \mathrm{~g} \mathrm{~N}, 0.025 \mathrm{~g}$ $\mathrm{P}_{2} \mathrm{O}_{5}, 0.020 \mathrm{~g} \mathrm{~K} \mathrm{O}_{2}$ and $5 \mathrm{~g}$ of corral manure per kg of quartzite tailings. V. zizanioides responded to $\mathrm{MF}$ at the recommended doses of $0.025 \mathrm{~g} \mathrm{~N}, 0.025 \mathrm{~g} \mathrm{P}_{2} \mathrm{O}_{5}$, and $0.020 \mathrm{~g} \mathrm{~K}_{2} \mathrm{O}$ per $\mathrm{kg}$ of tailings. It is concluded that quartzite tailings form a favorable habitat for $V$. zizanioides growth, mainly after being altered by MF.
\end{abstract}

Keywords: vetiveria zizanioides, nutrient concentrations, nutritional status, accumulation of nutrients, recommended doses. 


\section{INTRODUCTION}

The progressive increase of quartzite mining areas, mainly in response to anthropic activities, has aroused growing interest in society due to the impacts that may be caused to natural environments. The occurrence of degraded areas resulting from this activity in Brazil is becoming more frequent and worrying (Amaral et al., 2014).

According to information disclosed by environmental agencies, the amount of tailings generated in the quartzite extraction process can reach $90 \%$ of the extracted material. The large generated volume of tailings becomes a major problem for companies, with negative impacts such as landscape deconfiguration, alterations in the natural forms of the relief, silting of water bodies, and suppression of native vegetation, among others (Gentili et al., 2011).

Among the species used in restoration programs, the use of Vetiveria zizanioides, also known as Chrysopogon zizanioides (L.) (Roberty), can be distinguished due to its morphological and physiological characteristics, which have been widely known for their effectiveness in controlling erosion (Marques et al., 2007), and especially regarding heavy metal tolerance and adverse soil conditions (tolerance to high acidity, $\mathrm{Al}$ and $\mathrm{Mn}$ toxicity) (Truong et al., 2008). Vetiver is a species known to be excellent in ecological restoration (Xia \& Shu, 2001) and slope stabilization, mine rehabilitation, as well as in wastewater treatment (Truong et al., 2008), being used in more than 120 countries. Vetiver grass is a species belonging to the Poaceae family, is perennial, native to tropical and subtropical countries (India, China, Philippines, Indonesia), with the oil extracted from this species being widely used in the perfume industry as a basic element in perfume and as a fixing agent for odors of more volatile materials (Chitra et al., 2014). This species grows $0.5-1.5 \mathrm{~m}$ high with hard stems and in large clusters, forming a highly branched plant (Brandt et al., 2006; Truong et al., 2008). The root system is composed of fibrous roots that can reach depths of up to $3 \mathrm{~m}$ (Truong et al., 2008; Ramos et al., 2010; Marques et al., 2007).

The morphology and distribution of vetiver grass roots seem to be very well adapted to resist soil shearing (Marques et al., 2007). Numerous and long vetiver roots grow vertically downwards and are able to penetrate and strengthen soil, which may be subject to surface faults (Mickovski \& Van Beek, 2009). Poaceae plants play a key role in the recovery of degraded areas (Chong \& Chu, 2007; Marques et al., 2007), since they influence a constant renewal of soil aggregation by their extensive and abundant root system, being the main process for their recovery which occurs through the combined action of humidified organic matter, biological activity and plant roots (Ramos et al., 2010). These factors make it a promising species for recovering areas degraded by quartzite mining in Brazil.

Due to the absence of information of the $V$. zizanioides species under Brazilian conditions, the present study had the objective to evaluate the behavior of this species when cultivated in quartzite mining tailings under the influence of mineral and organic fertilization (OF) regarding its capacity to accumulate shoot biomass and nutrients, as well as to evaluate the macro and micro concentrations in the plant components.

\section{MATERIAL AND METHODS}

The experiment was conducted from August 2010 to December 2011 for 120 days under greenhouse conditions at the JK Campus of the Federal University of the Jequitinhonha and Mucuri Valleys (UFVJM) in Diamantina, state of Minas Gerais (MG), Brazil (18 $12^{\prime} \mathrm{S} 43^{\circ} 34^{\prime} \mathrm{W}$ and an altitude of $1,370 \mathrm{~m}$ ).

The substrate used in experiment was composed of quartzite mining tailings from mined areas located in the region of Diamantina. A sample was taken for chemical and texture analysis for characterizing the substrate. The sample was dried in the air and then passed through a sieve with $2.0 \mathrm{~mm}$-opening after which it was subjected to chemical (Silva, 2009) and texture analysis (EMBRAPA, 1997) (Table 1). The results of the chemical analysis were adjusted to the whole granulometric constitution of the quartzite tailings.

The experimental design was completely randomized with five combinations of OF and mineral fertilization (MF) and one additional treatment (control), with four replications. The amounts of $\mathrm{N}_{2} \mathrm{P}_{2} \mathrm{O}_{5}$, and $\mathrm{K}_{2} \mathrm{O}$ and corral manure in the combinations of MF and OF and in the control are shown in Table 2. The doses corresponding to $0.025 \mathrm{~g} \mathrm{~kg}^{-1}$ of $\left(\mathrm{NH}_{4}\right)_{2} \mathrm{SO}_{4}, 0.025 \mathrm{mg} \mathrm{kg}^{-1} \mathrm{P}_{2} \mathrm{O}_{5}$ (single superphosphate) and $0.020 \mathrm{mg} \mathrm{kg}^{-1} \mathrm{~K}_{2} \mathrm{O}$ (potassium chloride) were recommended for the 
Table 1. Chemical analysis and quartzite mining tail texture.

\begin{tabular}{|c|c|c|c|c|c|c|c|c|c|c|c|c|c|}
\hline \multirow{2}{*}{$\mathrm{pH}_{\text {water }}$} & $\mathbf{P}$ & $\mathbf{K}$ & $\mathrm{Ca}$ & Mg & Al & $\mathbf{T}$ & m & $\mathbf{V}$ & OM & $\begin{array}{l}\text { Gravel/ } \\
\text { Pebbles }\end{array}$ & Sand & Silt & Clay \\
\hline & \multicolumn{2}{|c|}{ - mg dm-3 -- } & \multicolumn{4}{|c|}{ 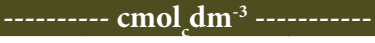 } & \multicolumn{2}{|c|}{----- \%------ } & & & o k & & ------ \\
\hline 5.0 & 1.2 & 5.3 & 0.5 & 0.2 & 0.2 & 1.7 & 24 & 41 & 7.1 & 340.4 & 554.0 & 99.0 & 6.6 \\
\hline
\end{tabular}

$\mathrm{pH}_{\text {water }}$ : soil-water ratio 1:2.5; P and K: Mehlich-1 extraction; Ca, Mg, and $\mathrm{Al}: \mathrm{KCl} 1 \mathrm{~mol} \mathrm{~L}^{-1}$ extraction; T: cation exchange capacity at $\mathrm{pH} 7.0$; m: aluminum saturation; V: base saturation; OM: organic matter determined by multiplying the organic carbon result by the Walkey-Black method by 1,724; Gravel/pebbles: sifted by a $2.0 \mathrm{~mm}$ sieve; Sand, silt, and clay: pipette method.

Table 2. Quantities of $\mathrm{N}, \mathrm{P}_{2} \mathrm{O}_{5}$ and $\mathrm{K}_{2} \mathrm{O}$ and corral manure for combinations of mineral (MF) and organic fertilization (OF) and control.

\begin{tabular}{|c|c|c|c|c|c|}
\hline MF & OF & $\mathbf{N}$ & $\mathbf{P}_{2} \mathbf{O}_{5}$ & $\mathrm{~K}_{2} \mathrm{O}$ & Corral manure \\
\hline \multicolumn{6}{|c|}{ 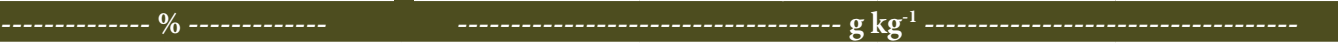 } \\
\hline 100 & 0 & 0.025 & 0.025 & 0.020 & 0 \\
\hline 75 & 25 & 0.019 & 0.019 & 0.015 & 1.25 \\
\hline 50 & 50 & 0.013 & 0.013 & 0.010 & 2.50 \\
\hline 25 & 75 & 0.006 & 0.006 & 0.005 & 3.75 \\
\hline 0 & 100 & 0 & 0 & 0 & 5.00 \\
\hline \multicolumn{2}{|c|}{ Control } & 0 & 0 & 0 & 0 \\
\hline
\end{tabular}

medium technological level of Brachiaria brizantha (Cantarutti et al., 1999). A 5 g dose of corral manure per $\mathrm{kg}$ of waste was recommended according to CFSEMG (1999). The chemical analyzes of cattle manure $(\mathrm{pH}=6.8, \mathrm{~N}=6.0, \mathrm{P}=1.5, \mathrm{~K}=1.3, \mathrm{Ca}=0.3$, $\mathrm{Mg}=0.4, \mathrm{~S}=0.8 ; \mathrm{B}=0.18, \mathrm{Cu}=0.008, \mathrm{Fe}=27.2$, $\mathrm{Mn}=0.13$ and $\mathrm{Zn}=0.065 \mathrm{~g} \mathrm{~kg}^{-1} ; \mathrm{C}$-organic $=178 \mathrm{~g} \mathrm{~kg}^{-1}$; and density $=0.69 \mathrm{~kg} \mathrm{dm}^{-3}$ ) were performed according to a methodology described by Melo \& Silva (2008). The experimental plot was composed of $5 \mathrm{~kg}$ plastic pots in which $3 \mathrm{~kg}$ of dry quartzite were placed, obtaining a uniform density of $0.93 \mathrm{~g} \mathrm{~cm}^{-3}$. The pots had the bottom sealed to prevent nutrient and water loss.

In installing the experiment, $0.12 \mathrm{~g}$ of dolomitic limestone per $\mathrm{kg}$ of quartzite was used to supply $\mathrm{Ca}$ and $\mathrm{Mg}$ by the base saturation method for elevating to 55\% (Alvarez Venegas \& Ribeiro, 1999). At the same time, phosphate fertilization and $\mathrm{OF}$ were carried out according to the MF and OF combinations described in Table 2. The tailings material was incubated for another 30 days, and the material moisture was maintained throughout the experiment at $60 \%$ of the total pore volume (TPV), measured daily by weighing, and with the weight being supplemented with deionized water. Basic fertilization of $0.0005 \mathrm{~g} \mathrm{~kg}^{-1}$ of $\mathrm{B}$ as boric acid and $0.001 \mathrm{~g} \mathrm{~kg}^{-1}$ of $\mathrm{Zn}$ in the form of zinc sulfate wer performed one week prior to sowing (Cantarutti et al., 1999).
V. zizanioides (L.) plants were supplied by the Deflor Bioengineering Company, in which 24 plants with uniform size (four plants per treatment) were selected and six treatments were designed as previously described. Roots were disintegrated and washed in distilled water and later transplanted into plastic vessels with bare roots.

Potassium and nitrogen fertilization in the covering began 15 days after the first uniform cut and were divided into four sessions with applications carried out at 15-day intervals. The standardization cut was performed at $0.03 \mathrm{~m}$ from the plant stem in order to standardize all treatments and start the experimental period. Four trials were performed during the experimental period at intervals of 35 days, and data on total shoot dry mass (SDM) production are presented in this work.

After collecting the plant material, it was washed in distilled water and dried in an oven with forced air circulation at $65^{\circ} \mathrm{C}$ for 72 hours until reaching constant weight to determine the SDM for each cut and root dry mass (RDM) at the end of the experiment.

The samples were analyzed for nutrient concentrations according to Malavolta et al. (1997) after milling the dry mass in order to evaluate the nutritional status of $V$. zizanioides (L.). To calculate the nutrient accumulation in shoots and roots, the concentration of each nutrient was multiplied by the dry mass of the 
analyzed components, thus the accumulation of each nutrient in the vetiver shoot and roots was obtained.

The data were submitted to analysis of variance. Regression equations were adjusted for the evaluated variables, with the dependent variable as a function of the percentage variations in $\mathrm{MF}$, and the independent variable with the coefficients of the regression equations tested by the $t$ test at $5 \%$. The MF percentage was estimated from the obtained equations to obtain the maximum vetiver shoot and root growth. The control mean was then compared with the mean MF percentages by the F-test at 5\%. The shoot nutrient content and accumulated in the shoot and roots of the vetiver were estimated, replacing the MF percentage for the maximum vetiver shoot growth in the equations that relate the MF percentage with these variables. SAS for Windows was used in all statistical procedures.

\section{RESULTS AND DISCUSSION}

The results showed vetiver ( $V$.zizanioides [L.] SDM $[\mathrm{p}=0.001], \mathrm{RDM}[\mathrm{p}=0.002]$, and total dry mass [TDM] $[\mathrm{p}=0.001])$ at 140 days after the standardization cut were only influenced by the MF combination (NPK) (Figure 1). The $\mathrm{N}, \mathrm{P}_{2} \mathrm{O}_{5}$, and $\mathrm{K}_{2} \mathrm{O}$ doses to obtain the maximum dry matter yield of the species under the study conditions were $0.025 \mathrm{~g} \mathrm{~N}, 0.025 \mathrm{~g} \mathrm{P}_{2} \mathrm{O}_{5}$ and $0.020 \mathrm{~g} \mathrm{~K}_{2} \mathrm{O}$ per kg of tailings, which corresponded to production of $2.63 \mathrm{~g}$ of SDM, $8.29 \mathrm{~g}$ of RDM, and $9.91 \mathrm{~g}$ per pot.

The control presented a significance difference $(\mathrm{p}=0.002)$, and it was lower than the other MF and OF combinations for the dry matter yield of vetiver grown in a greenhouse in quartzite mining tailings (Figure 1). This result confirms that fertilization is effective for $V$. zizanioides growing on low fertility substrate. It also indicates that fertilization is crucial in order to promote plant growth and consequently promote revegetation and habitat improvement in mining areas (Srivastava et al., 2008).

Vetiver shoot dry matter yield in quartzite tailings in the best treatment ( $100 \% \mathrm{MF}$ ) was lower than in a study with the same species in an environment contaminated with shale oil without fertilizer addition. This study was conducted in the southwest of Guangdong province, in a phytoremediation in soils contaminated by petroleum hydrocarbons in Venezuela with fertilization doses in uncontaminated soil which received basic doses of nitrogen $(\mathrm{N})$, phosphorus $(\mathrm{P})$ and potassium $(\mathrm{K})$ : $0.12 ; 0.06$ and $0.06 \mathrm{~g} \mathrm{~kg}^{-1}$ soil, in contaminated soils which were fertilized with low $\left(\mathrm{g} \mathrm{kg}^{-1}: 0.22 \mathrm{~N}, 0.11 \mathrm{P}\right.$, and $0.11 \mathrm{~K}$ ) and high levels ( $\mathrm{g} \mathrm{kg}^{-1}$ of soil: $0.30 \mathrm{~N}$, P 0.15, and 0.15 K) (Brandt et al., 2006) and in the restoration of abandoned and contaminated arsenic mines (Mickovski \& Van Beek, 2009).

In contrast, RDM yield $\left(8.29 \mathrm{~g} \mathrm{pot}^{-1}\right)$ was higher than SDM yield (2.63 g pot $\left.^{-1}\right)$ in the best MF combination (Figure 1). The main morphological characteristics of vetiver is its biomass production, and finely-structured, fast-growing deep root system (Cazzuffi et al., 2006; Marques et al., 2007). The ability to tolerate stressful conditions is another important required characteristic (Ghosh et al., 2015), and also being a species able to adapt to a wide range of edaphoclimatic conditions

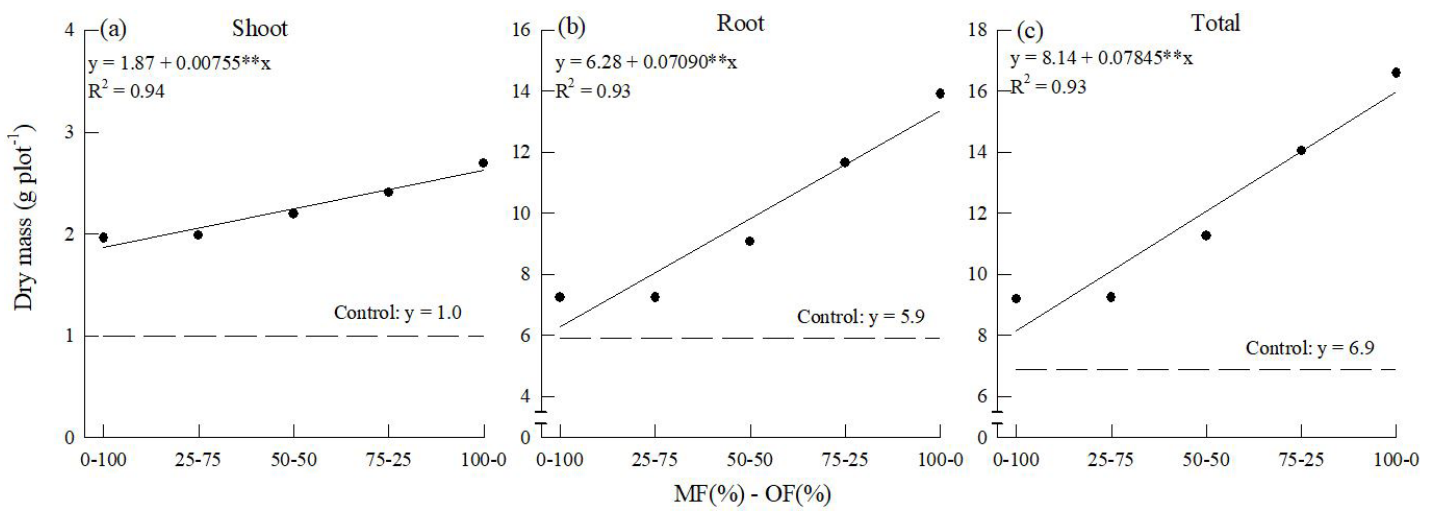

Figure 1. Shoot (a), root (b), and total dry mass (TDM) (c) of Vetiveria zizanioides in relation to the mineral (MF) and organic (OF) fertilization percentage applied on quartzite mineral tailings in a period of 140 days after the standardization cut ${ }^{* *}$ significant at $1 \%$ by the $t$ test $)$. 
throughout the tropics and subtropics (Cazzuffi et al., 2006; Truong et al., 2008).

The high biomass potential of vetiver observed with the $100 \% \mathrm{MF}$ treatment is due to the positive effect of MF. This effect on the shoot and root biomass yield is related to changes in the chemical properties of the substrate through the supply of nutrients (Figure 1). This response is reinforced by the ability of vetiver roots to penetrate and reinforce the soil by the large number of long roots growing vertically downwards (Mickovski \& Van Beek; 2009, Marques et al., 2007) and roots in constant renewal in the aggregates and combined action with humidified organic matter, microbiological activity, and plant roots (Ramos et al., 2010).

Positive responses to MF in degraded areas were observed with different grass and legume forages in recovery of chemical and physical properties of a degraded soil in dry matter yield in the degraded area, in which they applied $0.022 \mathrm{~g} \mathrm{~kg}^{-1} \mathrm{~N}, 0.080 \mathrm{~g} \mathrm{~kg}^{-1} \mathrm{P}_{2} \mathrm{O}_{5}$, $0.075 \mathrm{~g} \mathrm{~kg}^{-1} \mathrm{~K}_{2} \mathrm{O}$ and $6.6 \mathrm{~g} \mathrm{~kg}^{-1}$ of corral manure (Favaretto et al., 2000).

The concentrations of all nutrients were influenced by the MF, except for the concentrations of $\mathrm{N}, \mathrm{Ca}$, $\mathrm{Mg}, \mathrm{B}$, and $\mathrm{Fe}$ in the vetiver shoot, and all nutrients differed from the control (Table 3 ). For species in an area degraded by quartzite extraction, and as there is no information on vetiver leaf concentration in these conditions, comparisons of the shoot concentrations were performed with studies in which they defined the appropriate ranges for the nutrient concentrations in forage grasses. The comparisons were performed only as a reference, since the contents vary with the conditions, growing times, and age, among others.

The $\mathrm{N}$ content $\left(17.10 \mathrm{~g} \mathrm{~kg}^{-1}\right)$ in the vetiver SDM cultivated in quartzite tailings with $100 \% \mathrm{MF}$ in which it gave the highest SDM yield at 140 days is within the suitable range for forage grasses recommended by Malavolta et al. (1997), which varies from 13 to $20 \mathrm{~g} \mathrm{~kg}^{-1}$. When comparing the $\mathrm{N}$ content between the control and $100 \% \mathrm{MF}$, the control concentration was higher and is above the appropriate range; this result is due to the concentration effect (Malavolta, 2006).

The $\mathrm{P}$ concentration $\left(1.89 \mathrm{~g} \mathrm{~kg}^{-1}\right)$ in $V$. zizanioides shoots in $100 \% \mathrm{MF}$ is within the appropriate range of 0.8 to $3.0 \mathrm{~g} \mathrm{~kg}^{-1}$ (Werner et al., 1996) for forage grasses. The $\mathrm{P}$ concentration in the control vetiver shoots is P deficient (Table 3) (Werner et al., 1996). This shows that the applied $\mathrm{P}$ amount in the best treatment to obtain the maximum SDM yield was sufficient to meet the nutritional demand and that the phosphate fertilization is responsive in the initial growth and in the production of V. zizanioides. $\mathrm{P}$ is considered a determining nutrient in plant growth, since it has considerable importance in carbon metabolism, as well as in forming phosphate sugars (Malavolta, 2006).

With $100 \%$ MF, the K leaf concentration $\left(18.69 \mathrm{~g} \mathrm{~kg}^{-1}\right)$ for $V$. zizanioides is found to be above the suitable range for forage grasses of 12 to $13 \mathrm{~g} \mathrm{~kg}^{-1}$ (Werner et al., 1996). There was a lower $\mathrm{K}$ concentration in the control

Table 3. Regression equations adjusted for nutrient concentration in the Vetiveria zizanioides shoots in relation to the mineral fertilization (MF) percentage applied to quartzite mineral tailings, nutrient concentration corresponding to $100 \%$ of $\mathrm{MF}$ and in the control $(0 \%$ of OF) for a period of 140 days after the standardization cut.

\begin{tabular}{|c|c|c|c|c|}
\hline Nutrient $^{(1)}$ & Regression equation & $\mathbf{R}^{2}$ & $\mathrm{MF}^{(2)}$ & Control $(0 \% \text { OF })^{(3)}$ \\
\hline $\mathrm{N}$ & $\hat{y}=\bar{y}=17.10$ & - & $17.10^{(3)}$ & $21.99^{*}$ \\
\hline $\mathrm{P}$ & $\hat{y}=1.06+0.0083^{* *} x$ & 0.90 & 1.89 & $0.59^{*}$ \\
\hline K & $\hat{y}=15.53+0.0316^{* *} x$ & 0.92 & 18.69 & $10.23^{*}$ \\
\hline $\mathrm{Ca}$ & $\hat{y}=\bar{y}=1.26$ & - & $1.26^{(3)}$ & $2.16^{*}$ \\
\hline $\mathrm{Mg}$ & $\hat{y}=\bar{y}=0.29$ & - & $0.29^{(3)}$ & $0.39^{*}$ \\
\hline $\mathrm{S}$ & $\hat{y}=2.49+0.0303^{* *} x$ & 0.85 & 5.52 & $2.32^{*}$ \\
\hline B & $\hat{y}=\bar{y}=43.38$ & - & $43.38^{(3)}$ & $62.19^{*}$ \\
\hline $\mathrm{Cu}$ & $\hat{y}=13.20-0.0577^{\star \star} x$ & 0.81 & 7.43 & $32.38^{*}$ \\
\hline $\mathrm{Fe}$ & $\hat{y}=\bar{y}=68.44$ & - & $68.44^{(3)}$ & $111.10^{*}$ \\
\hline $\mathrm{Mn}$ & $\hat{y}=183.11-0.9783^{\star *} x$ & 0.92 & 85.29 & $59.78^{*}$ \\
\hline $\mathrm{Zn}$ & $\hat{y}=46.34-0.3360^{\star \star} x+0.0065^{\star \star} x^{2}$ & 0.98 & 77.67 & $44.70^{*}$ \\
\hline
\end{tabular}

${ }^{*}$ Differentiates the control from the other treatments by the F-test at $5 \%$; ${ }^{*}$ significant at $1 \%$ by the $t$ test for the coefficients of the regression equations; ${ }^{(1)}$ Macronutrients in $\mathrm{g} \mathrm{kg}^{-1}$ and micronutrients in $\mathrm{mg} \mathrm{kg}^{-1}$; ${ }^{(2)}$ Nutrient concentration in the $100 \% \mathrm{MF}$ and control ( $0 \%$ organic - OF) application; ${ }^{(3)}$ Mean concentration of MF and OF combinations. 
possibly due to the fact that no fertilizer was applied in this treatment, since the K concentration in the dry mass also varies with the nutrient's availability in the soil (Kano et al., 2010).

In the SDM of $V$. zizanioides grown in quartzite tailings with $100 \% \mathrm{MF}$, the $\mathrm{Ca}\left(1.26 \mathrm{~g} \mathrm{~kg}^{-1}\right)$ and $\mathrm{Mg}$ concentration $\left(0.29 \mathrm{~g} \mathrm{~kg}^{-1}\right)$ are below the adequate range recommended by Werner et al. (1996) for forage grasses. The very sandy texture of the substrate with low cation exchange capacity (T) (Table 1) provides lower limestone recommendation due to low buffering power (Sambatti et al., 2003), and consequently reduced $\mathrm{Ca}$ and $\mathrm{Mg}$ availability.

Regarding the $\mathrm{S}$ macronutrient, the control concentration differed from the MF and $\mathrm{OF}$ combinations (Table 3). While the $\mathrm{S}$ concentration $\left(5.52 \mathrm{~g} \mathrm{~kg}^{-1}\right)$ at $100 \% \mathrm{MF}$ in the grass area is above the appropriate range, and in the control $\left(2.32 \mathrm{~g} \mathrm{~kg}^{-1}\right)$ it is within the adequate range of 0.8 to $2.5 \mathrm{~g} \mathrm{~kg}^{-1}$ (Werner et al., 1996). The higher S concentration in the $100 \%$ MF application can be explained by the use of ammonium sulphate as the $\mathrm{N}$ source.

The B content $\left(43.38 \mathrm{~g} \mathrm{~kg}^{-1}\right)$ in the shoots of $V$. zizanioides in the $100 \%$ MF combination (Table 3) is above the appropriate range for forage grasses of 10 to $25 \mathrm{~g} \mathrm{~kg}^{-1}$ (Werner et al., 1996). The excess of B in the best treatment was due to the complementary fertilization carried out with boric acid in the sandy texture substrate (Table 1), with sandy soil having higher availability of B (Malavolta, 2006).

The $\mathrm{Cu}$ concentration $\left(7.43 \mathrm{mg} \mathrm{kg}^{-1}\right)$ in the vetiver grass shoot is in the range suitable for forage grasses of 7 to $10 \mathrm{mg} \mathrm{kg}^{-1}$ (Werner et al., 1996) for $100 \% \mathrm{MF}$ application. A higher concentration (32.38 $\mathrm{mg} \mathrm{kg}^{-1}$ ) was observed in the control (Table 3 ), as the nutrient demands in both treatments were supplied via substrate, since fertilization with copper was not performed.

The Fe concentration $\left(68.44 \mathrm{mg} \mathrm{kg}^{-1}\right.$ ) with $100 \% \mathrm{MF}$ in the $V$. zizanioides shoot is below the appropriate range of 196 to $239 \mathrm{mg} \mathrm{kg}^{-1}$ (Werner et al., 1996) for forage grasses, and the same occurs in the control (Table 3). This is possibly due to the characteristic of the substrate which presents low clay concentration (Table 1) as sandy soils have low Fe availability (Barbieri et al., 2013), and because Fe was not applied.

The $\mathrm{Zn}$ concentration $\left(77.67 \mathrm{mg} \mathrm{kg}^{-1}\right)$ in $100 \% \mathrm{MF}$ is above the suitable range for grasses of 29 to $35 \mathrm{mg} \mathrm{kg}^{-1}$
(Werner et al., 1996). This is mainly due to the $\mathrm{Zn}$ application and the physical characteristics of the sandy texture substrate (Table 1), thus reducing the adsorption points and consequently the greater $\mathrm{Zn}$ availability to the forage. The adsorption is perhaps the main process to be considered for understanding $\mathrm{Zn}$ availability in the soil, since it gives indications of the solubility and mobility of this micronutrient and its consequent availability to the plants (Nascimento \& Fontes, 2004).

There is no detailed information on nutrient accumulation by vetiver in degraded areas, and specifically even less in quartzite extraction areas. The information on the accumulation is insufficient and is limited to a few works. In this work, we observed a significant effect $(\mathrm{p}=0.001)$ for $\mathrm{N}, \mathrm{P}, \mathrm{K}, \mathrm{B}, \mathrm{Cu}, \mathrm{Mn}$, and $\mathrm{Zn}$ accumulation in $\mathrm{V}$. zizanioides in relation to the MF percentage, but not for $\mathrm{Ca}, \mathrm{Mg}$, and $\mathrm{Fe}$ (Table 4). It is verified that the accumulated values of nutrients by the control grass were always inferior (Table 4) to $100 \% \mathrm{MF}$; this is generally due to the lower SDM production (Figure 1).

Among the macronutrients, the highest accumulations in the forage shoot and root were $\mathrm{N}$ and $\mathrm{K}$, and $\mathrm{P}$ accumulated in smaller amounts (Table 4). The accumulated values for the macronutrients in the shoot presented the following accumulation order: $\mathrm{K}>\mathrm{N}>\mathrm{S}>\mathrm{P}>\mathrm{Ca}>\mathrm{Mg}$ (Table 4). For the micronutrients, a decreasing order of accumulated quantities occurred in the shoot as $\mathrm{Mn}>\mathrm{Zn}>\mathrm{Fe}>\mathrm{B}>\mathrm{Cu}$ (Table 4).

With the aim to use species in recovery projects, the nutrient accumulation by the species was lower than those found by Salton et al. (2008) in a study on nutrient dynamics in Deciduous Seasonal Forest, where $\mathrm{K}$ was the element that accumulated most, followed by $\mathrm{N}$

The highest accumulations of $\mathrm{N}, \mathrm{Ca}, \mathrm{Mg}, \mathrm{S}, \mathrm{Cu}, \mathrm{Fe}$, and $\mathrm{Zn}$ nutrients were obtained with 100\% MF and in control of vetiver roots (Table 4), mainly due to the higher RDM production (Figure 1).

The accumulated values for the macronutrients in the root for $100 \% \mathrm{MF}$ presented the following accumulation order: $\mathrm{N}>\mathrm{S}>\mathrm{Ca}>\mathrm{K}>\mathrm{Mg}>\mathrm{P}$ (Table 4 ). While for the micronutrients accumulated in the root, the decreasing order of quantities occurred as $\mathrm{Fe}>\mathrm{Zn}>\mathrm{B}>\mathrm{Mn}>\mathrm{Cu}$ (Table 4). 
Table 4. Regression equations adjusted for macro and micronutrient accumulation in the shoot and root dry mass (RDM) of Vetiveria zizanioides in relation to the mineral fertilization (MF) percentage applied in quartzite mineral tailings, the maximum accumulation (MF) of nutrients and in the control, in a period of 140 days after the standardization cut.

\begin{tabular}{|c|c|c|c|c|}
\hline Nutrient ${ }^{(1)}$ & Regression equation & $\mathbf{R}^{2}$ & MF $^{(2)}$ & Control (OF) (3) \\
\hline \multicolumn{5}{|l|}{ Shoot } \\
\hline $\mathrm{N}$ & $\hat{y}=30.93+0.1501^{* *} x$ & 0.88 & 45.94 & $22.00^{*}$ \\
\hline $\mathrm{P}$ & $\hat{y}=2.30+0.0201^{* *} x$ & 0.91 & 4.31 & $0.59^{*}$ \\
\hline $\mathrm{K}$ & $\hat{y}=32.52+0.1165^{\star \star} x$ & 0.91 & 44.17 & $10.23^{*}$ \\
\hline $\mathrm{Ca}$ & $\hat{y}=\bar{y}=2.84$ & - & $2.84^{(3)}$ & 2.16 \\
\hline $\mathrm{Mg}$ & $\hat{y}=\bar{y}=0.64$ & - & $0.64^{(3)}$ & $0.39^{*}$ \\
\hline S & $\hat{y}=4.43+0.0963^{\star *} x$ & 0.97 & 14.06 & $2.32^{*}$ \\
\hline $\mathrm{B}$ & $\hat{y}=72.48+0.9437^{\star *} x-0.0061^{\star *} x^{2}$ & 0.93 & 105.85 & $62.23^{\star}$ \\
\hline $\mathrm{Cu}$ & $\hat{y}=22.27+0.1877^{\star *} x-0.0024^{\star *} x^{2}$ & 0.87 & 17.04 & $32.40^{*}$ \\
\hline $\mathrm{Fe}$ & $\hat{y}=\bar{y}=152.65$ & - & $152.65^{(3)}$ & $111.18^{*}$ \\
\hline Mn & $\hat{y}=383.83-1.7897^{* *} x$ & 0.84 & 204.86 & $59.82^{*}$ \\
\hline $\mathrm{Zn}$ & $\hat{y}=94.39-0.8229^{* *} x+0.0189^{* *} x^{2}$ & 0.99 & 201.10 & $44.73^{*}$ \\
\hline \multicolumn{5}{|c|}{ (i } \\
\hline $\mathrm{N}$ & $\hat{y}=66.69-0.3819^{* *} x+0.0107^{\star *} x^{2}$ & 0.96 & 135.50 & $59.94^{*}$ \\
\hline $\mathrm{P}$ & $\hat{y}=0.63+0.0053^{\star \star} x$ & 0.90 & 1.16 & $0.41^{\star}$ \\
\hline K & $\hat{y}=28.16+0.1084^{\star *} x$ & 0.93 & 24.22 & $14.81^{*}$ \\
\hline $\mathrm{Ca}$ & $\hat{y}=15.19+0.4572^{* *} x$ & 0.95 & 60.91 & $16.39^{*}$ \\
\hline $\mathrm{Mg}$ & $\hat{y}=\bar{y}=1.43$ & - & $1.43^{(3)}$ & $0.68^{*}$ \\
\hline S & $\hat{y}=25.97+0.4058^{\star *} x$ & 0.85 & 66.55 & $10.24^{\star}$ \\
\hline $\mathrm{B}$ & $\hat{y}=348.99-1.9523^{* *} x+0.0246^{* *} x^{2}$ & 0.86 & 399.76 & 300.98 \\
\hline $\mathrm{Cu}$ & $\hat{y}=37.17-0.3581^{\star *} x+0.0049^{* *} x^{2}$ & 0.86 & 50.36 & $24.89^{\star}$ \\
\hline $\mathrm{Fe}$ & $\hat{y}=6.852 .51-151.2001^{\star *} x+1.2415^{\star *} x^{2}$ & 0.90 & 4.147 .50 & 3.220 .33 \\
\hline $\mathrm{Mn}$ & $\hat{y}=570.10+5.6924^{* *} x-0.1072^{* *} x^{2}$ & 0.99 & 67.34 & $16.22^{*}$ \\
\hline $\mathrm{Zn}$ & $\hat{y}=360.42+7.7801^{* *} x$ & 0.90 & 1.138 .43 & $98.58^{*}$ \\
\hline
\end{tabular}

${ }^{*}$ Differentiates the control of the other treatments by the F-test at $5 \%$; ${ }^{* *}$ significant at $1 \%$ by the $t$ test for the regression equation coefficients; ${ }^{(1)}$ Macronutrients in $\mathrm{mg} \mathrm{pot}^{-1}$ and micronutrients in $\mu \mathrm{g} \mathrm{pot}^{-1}{ }^{-12}$ Maximum accumulation in the $100 \% \mathrm{MF}$ and $0 \%$ organic (OF) application; ${ }^{(3)}$ Mean accumulation of the MF and OF combinations.

\section{CONCLUSIONS}

1. Quartzite tailings with NPK MF is a favorable habitat for $V$. zizanioides growth;

2. An MF with the corresponding doses of $0.025 \mathrm{~g} \mathrm{~N}, 0.025 \mathrm{~g} \mathrm{P}_{2} \mathrm{O}_{5}$ and $0.020 \mathrm{~g} \mathrm{~K}_{2} \mathrm{O}$ per $\mathrm{kg}$ of quartzite tailings is recommended for the vetiver cultivar;

3. The nutrient content in the $V$. zizanioides shoots was $17.10 \mathrm{~g} \mathrm{~kg}^{-1}$ for $\mathrm{N}, 1.89 \mathrm{~g} \mathrm{~kg}^{-1}$ for $\mathrm{P}, 18.69 \mathrm{~g} \mathrm{~kg}^{-1}$ for $\mathrm{K}, 1.26 \mathrm{~g} \mathrm{~kg}^{-1}$ for $\mathrm{Ca}, 0.29 \mathrm{~g} \mathrm{~kg}^{-1}$ for $\mathrm{Mg}$, $5.52 \mathrm{~g} \mathrm{~kg}^{-1}$ for S, $43.38 \mathrm{mg} \mathrm{kg}^{-1}$ for B, $7.43 \mathrm{mg} \mathrm{kg}^{-1}$ for $\mathrm{Cu}, 68.44 \mathrm{mg} \mathrm{kg}^{-1}$ for $\mathrm{Fe}, 85.29 \mathrm{mg} \mathrm{kg}^{-1}$ for $\mathrm{Mn}$, and $77.67 \mathrm{mg} \mathrm{kg}^{-1}$ for $\mathrm{Zn}$;

4. The accumulation of nutrients in $V$. zizanioides at the recommended doses occurred in the following order in the shoots for macronutrients: $\mathrm{K}>\mathrm{N}>\mathrm{S}>\mathrm{P}>\mathrm{Ca}>\mathrm{Mg}$; and for micro: $\mathrm{Mn}>\mathrm{Zn}>\mathrm{Fe}>\mathrm{B}>\mathrm{Cu}$; and in the roots for macro: $\mathrm{N}>\mathrm{S}>\mathrm{Ca}>\mathrm{K}>\mathrm{Mg}>\mathrm{P}$; and for micro: $\mathrm{Fe}>\mathrm{Zn}>\mathrm{B}>\mathrm{Mn}>\mathrm{Cu}$.

\section{ACKNOWLEDGEMENTS}

The authors wish to thank CNPq (Conselho Nacional de Desenvolvimento Científico e Tecnológico) for grant funding for this research and Universidade Federal dos Vales do Jequitinhonha for all support during the execution of the work.

\section{SUBMISSION STATUS}

Received: 2 june, 2016

Accepted: 30 june, 2018

\section{CORRESPONDENCE TO}

\section{Cristiany Amaral}

Campus JK, Rodovia MGT 367, Km 583, 5000, Alto da Jacuba, CEP 39100-000, Diamantina, MG, Brasil

e-mail: cristianyamaral@yahoo.com.br 


\section{FINANCIAL SUPPORT}

The authors wish to thank $\mathrm{CNPq}$ (Conselho Nacional de Desenvolvimento Científico e Tecnológico) for grant funding for this research and Universidade Federal dos Vales do Jequitinhonha for all support during the execution of the work.

\section{REFERENCES}

Alvarez Venegas VH, Ribeiro AC. Calagem. In: Ribeiro AC, Guimarães PTG, Alvarez Venegas VH, editores. Recomendações para o uso de corretivos e fertilizantes em Minas Gerais. Viçosa: CFSEMG; 1999.

Amaral CS, Silva EB, Pereira IM, Nardis BO, Gonçalves $\mathrm{NH}$, Amaral WG. Crescimento da candeia pela adubação mineral e orgânica em rejeito da mineração de quartzito. Floresta 2014; 44(3): 421-430. http://dx.doi.org/10.5380/ rf.v44i3.32250.

Barbieri DM, Marques J Jr, Pereira GT Jr, La Scala N Jr, Siqueira DS, Panosso AR. Comportamento dos óxidos de ferro da fração argila e do fósforo adsorvido, em diferentes sistemas de colheita de cana-de-açúcar. Revista Brasileira de Ciência do Solo 2013; 37(6): 1557-1568. http://dx.doi. org/10.1590/S0100-06832013000600012.

Brandt R, Merkl N, Schultze-Kraft R, Infante C, Broll G. Potential of vetiver (Vetiveria zizanioides (L.) Nash) for phytoremediation of petroleum hydrocarboncontaminated soils in Venezuela. International Journal of Phytoremediation 2006; 8(4): 273-284. http://dx.doi. org/10.1080/15226510600992808. PMid:17305302.

Cantarutti RB, Martins CE, Carvalho MM, Fonseca DM, Arruda ML, Vilela HEE et al. Pastagens. In: Ribeiro AC, Guimarães PTG, Alvarez Venegas VH, editores. Recomendações para o uso de corretivos e fertilizantes em Minas Gerais. Viçosa: CFSEMG; 1999.

Cazzuffi D, Corneo A, Crippa E. Slope stabilisation by perennial "gramineae" in Southern Italy: plant growth and temporal performance. Geotechnical and Geological Engineering 2006; 24(3): 429-447. http://dx.doi.org/10.1007/ s10706-005-4144-9.

Chitra T, Jayashree S, Rathinamala J. Preliminary studies in vitro regeneration of Vetiveria zizanioides through meristem tip culture. Journal of Bio Innovation 2014; 4: 189-196.

Chong, C. W.; Chu, L. M. Growth of vetiver grass for cut slope landscaping: effects of container size and watering rate. Urban Forestry and Urban Greening 2007; 6(3):135141. http://dx.doi.org/10.1016/j.ufug.2007.07.002.

Comissão de Fertilidade do Solo do Estado de Minas Gerais - CFSEMG. Adubação orgânica. In: Ribeiro AC, Guimarães PTG, Alvarez Venegas VH, editores.
Recomendações para o uso de corretivos e fertilizantes em Minas Gerais. Viçosa: CFSEMG; 1999.

Empresa Brasileira de Pesquisa Agropecuária - EMBRAPA. Manual de métodos de análise de solo. Rio de Janeiro: CNPS; 1997.

Favaretto N, Moraes A, Motta ACV, Prevedello BMS. Efeito da revegetação e da adubação de área degradada na fertilidade do solo e nas características da palhada. Pesquisa Agropecuária Brasileira 2000; 35(2): 289-297. http://dx.doi.org/10.1590/S0100-204X2000000200007.

Gentili R, Sgorbati S, Baroni C. Plant species patterns and restoration perspectives in the highly disturbed environment of the carrara marble quarries (Apuan Alps, Italy). Restoration Ecology 2011; 19(101): 32-42. http:// dx.doi.org/10.1111/j.1526-100X.2010.00712.x.

Ghosh M, Paul J, Jana A, Mukherjee A. Use of the grass, Vetiveria zizanioides (L.) Nash for detoxification and phytoremediation of soils contaminated with fly ash from thermal power plants. Ecological Engineering 2015; 74: 258-265. http://dx.doi.org/10.1016/j.ecoleng.2014.10.011.

Kano C, Cardoso A, Villas Bôas RL. Influência de doses de potássio nos teores de macronutrientes em plantas e sementes de alface. Horticultura Brasileira 2010; 28(3): 287291. http://dx.doi.org/10.1590/S0102-05362010000300008.

Malavolta E, Vitti GC, Oliveira SA. Avaliação do estado nutricional das plantas: princípios e aplicações. 2. ed. Piracicaba: POTAFOS; 1997.

Malavolta E. Manual de nutrição mineral de plantas. São Paulo: Agronômica Ceres; 2006.

Marques TED, Baeta HE, Leite MGP, Martins SV, Kozovits AR. Crescimento de espécies nativas de Cerrado e de Vetiveria zizanioides em processos de revegetação de voçorocas. Ciência Florestal 2007; 24(4): 843-856. http:// dx.doi.org/10.1590/1980-509820142404005.

Melo LCA, Silva CA. Influência de métodos de digestão e massa de amostra na recuperação de nutrientes em resíduos orgânicos. Quimica Nova 2008; 31(3): 556-561. http://dx.doi.org/10.1590/S0100-40422008000300018.

Mickovski SB, Van Beek LPH. Root morphology and effects on soil reinforcement and slope stability of young vetiver (Vetiveria zizanioides) plants grown in semi-arid climate. Plant and Soil 2009; 324(1-2): 43-56. http://dx.doi. org/10.1007/s11104-009-0130-y.

Nascimento CWA, Fontes RLF. Correlação entre características de latossolos e parâmetros de equações de adsorção de cobre e zinco. Revista Brasileira de Ciência do Solo 2004; 28(6): 965-971. http://dx.doi.org/10.1590/ S0100-06832004000600004.

Ramos FT, Monari YC, Nunes MCM, Campos DTS, Ramos DT. Indicadores de qualidade em um Latossolo Vermelho-Amarelo sob pastagem extensiva no pantanal matogrossense. Revista Caatinga 2010; 23(1): 112-120. 
Salton JC, Mielniczuk J, Bayer C, Boeni M, Conceição PC, Fabrício AC et al. Agregação e estabilidade de agregados do solo em sistemas agropecuários em Mato Grosso do Sul. Revista Brasileira de Ciência do Solo 2008; 32(1): 1121. http://dx.doi.org/10.1590/S0100-06832008000100002.

Sambatti JA, Souza IG Jr, Costa ACS, Tormena CA. Estimativa da acidez potencial pelo método do $\mathrm{pH}$ SMP em solos da formação caiuá - noroeste do estado do Paraná. Revista Brasileira de Ciência do Solo 2003; 27(2): 257-264. http://dx.doi.org/10.1590/S0100-06832003000200006.

Silva FC. Manual de análises químicas de solos, plantas e fertilizantes. 2. ed. Brasília: Embrapa Informações Tecnológicas; 2009.

Srivastava J, Kayastha S, Jamil S, Srivastava V. Environmental perspectives of Vetiveria zizanioides (L.) Nash. Acta
Physiologiae Plantarum 2008; 30(4): 413-417. http:// dx.doi.org/10.1007/s11738-008-0137-7.

Truong P, Tran Van T, Pinners E. Vetiver system applications: a technical reference manual. 2 ed. Thailand: The Vetiver Network International; 2008.

Werner JC, Paulino VT, Cantarella H. Forrageiras. In: van Raij B, Cantarella H, Quaggio JA, Furlani AMC, editores. Recomendações de adubação e calagem para o Estado de São Paulo. Campinas: Instituto Agronômico; 1996.

Xia HP, Shu WS. Resistance to and uptake of heavy metals by Vetiveria zizanioides and Paspalumnotatum from lead/zinc mine tailings. Acta Ecologica Sinica 2001; 21(7): 1121-1129. 